\title{
Analisis Sektor Basis Perikanan dan Komoditas Unggulan di Kabupaten Karimun
}

\author{
Ismu Kusumanto ${ }^{1}$, Anwardi' ${ }^{2}$, Pitriya Anggeon Sari ${ }^{3}$, Wresni Anggraini ${ }^{4}$, Nofirza ${ }^{5}$ \\ $1,2,3,4,5)$ Fakultas Sains dan Teknologi, Jurusan Teknik Industri, UIN Suska Riau \\ Jl. HR. Soebrantas No. 155, Pekanbaru 28293 \\ Email: Ismu@uin-suska.ac.id, anwardi@uin-suska.ac.id, Pitriyaanggunsr@gmail.com,
}

\begin{abstract}
Karimun Regency is the one of the regions that is in the development of increasing economic growth and has considerable business opportunities to increase regional economic growth. Karimun regency has natural resources that are still very potential to be developed. Business sector distribution indicators to see the rate of economic growth can be indicated by the number of Gross Regional Domestic Product, indicate that the average growth of the economic sector that provides a largest distrbution from 2010-2017 is the agriculture, forestry and fisheries sector which is equal to 17,05\% and subsector which provides the largest distribution is the fisheries sector in the amount of $71,61 \%$. However, from 2010-2017 the agriculturue, forestry and fisheries sector experienced a slowdown in economic growth of 2,76\%. This research aims to analyze the base sector in the fisheries sector using the approach Location Quotient (LQ) method, afterwards the sector which is the potential sector or base is analyzed using the approach Analytical Hierarchy Process (AHP) to determine the leading commodities in the base sector. Results of this research indicate that the sector is the base sector and the main concern of the regional government in increasing regional economic growth in the fisheries sector is the capture fisheries subsector with the value of $L Q>1$, that is 1,32 and the leading commodities in the capture fisheries subsector are cuttlefish with a growth of 0,40 the followed by large pelagic fish 0,30 andthen shrimp commodities of 0,17 and the last is small pelagic fish of 0,12.
\end{abstract}

Keywords : Regional Economic Growth, Fisheries Sector, Location Quotient, Analytical Hierarchy Process

\begin{abstract}
Abstrak
Kabupaten Karimun merupakan salah satu daerah yang sedang dalam pengembangan peningkatan laju pertumbuhan ekonomi dan memiliki peluang lapangan usaha yang cukup banyak untuk meningkatkan pertumbuhan ekonomi daerah. Kabupaten Karimun memiliki sumberdaya alam yang masih sangat potensial untuk dikembangkan. Indikator distribusi lapangan usaha untuk melihat laju pertumbuhan ekonomi dapat ditunjukkan oleh angka Produk Domestik Regional Bruto (PDRB), rata-rata pertumbuhan sektor ekonomi yang memberikan distribusi paling besar dari tahun 2010-2017 yaitu sektor pertanian, kehutanan dan perikanan sebesar $17,05 \%$ dan subsektor yang memberikan distribusi paling besar adalah sektor perikanan sebesar 71,61\%. Namun, dari tahun 2010-2017 sektor pertanian, kehutanan, dan perikanan mengalami perlambatan laju pertumbuhan ekonomi sebanyak $2,76 \%$. Penelititan ini bertujuan untuk menganalisis sektor basis pada sektor perikanan menggunakan pendekatan metode Location Quotient (LQ), kemudian sektor yang merupakan sektor potensial atau basis dianalisis menggunakan pendekatan Analytical Hierarchy Process (AHP) untuk menentukan komoditas unggulan pada sektor basis. Hasil dari penelitian menunjukkan bahwa sektor yang merupakan sektor basis dan menjadi perhatian utama pemerintah daerah dalam peningkatan pertumbuhan ekonomi daerah pada sektor perikanan adalah subsektor perikanan tangkap dengan nilai $\mathrm{LQ}>1$ yaitu 1,32 dan komoditas unggulan pada subsektor perikanan tangkap adalah komoditas sotong dengan bobot 0,40 kemudian disusul dengan ikan pelagis besar dengan bobot 0,30 lalu komoditas udang 0,17 dan terakhir adalah komoditas ikan pelagis kecil dengan bobot 0,12.
\end{abstract}

Kata Kunci : Pertumbuhan Ekonomi Daerah, Sektor Perikanan, Location Quotient, Analytical Hierarchy Process

\section{Pendahuluan}

Pertumbuhan ekonomi daerah merupakan salah satu unsur penting dalam proses pembangunan ekonomi nasional. Pertumbuhan ekonomi daerah juga sangat tergantung dengan potensi yang dimiliki oleh masing-masing daerah. Pemanfaatan potensi yang dimiliki daerah merupakan hal mutlak dalam pembangunan ekonomi. Potensi daerah yang dikelola secara baik dapat berdampak positif serta perekonomian daerah akan menjadi stabil. 
Potensi ekonomi daerah yang layak dikembangkan dan pemanfaatan sumberdaya alam yang ada serta berorientasi pada keunggulan lokal bisa meningkatkan laju pertumbuhan ekonomi daerah (Sapriadi dan Hasbiullah, 2015).

Kabupaten Karimun merupakan salah satu daerah yang sedang dalam pengembangan peningkatan laju pertumbuhan ekonomi dan memiliki peluang lapangan usaha yang berpotensi untuk meningkatkan laju pertumbuhan ekonomi yang didukung dengan memiliki sumberdaya alam yang melimpah. Laju pertumbuhan ekonomi itu sendiri dapat dilihat pada angka Produk Domestik Regional Bruto (PDRB) yang mengidentifikasi atau jasa yang selanjutnya digunakan sebagai dasar perencanaan dan evaluasi pembangunan serta pertumbuhan ekonomi daerah (Tjandra, 2009).

Pemanfaatan potensi yang dimiliki daerah mampu menciptakan jumlah dan jenis peluang kerja baru untuk masyarakat daerah. Sehingga pemerintah dan masyarakat harus bekerjasama untuk membangun potensi ekonomi daerah yang layak dikembangkan dan memanfaatkan sumberdaya alam yang ada dan salah satu caranya yaitu berorientasi pada keunggulan lokal untuk meningkatkan laju pertumbuhan ekonomi daerah (Sapriadi dan Hasbiullah, 2015).

Indikator lapangan usaha yang ada di Kabupaten Karimun berjumlah 17 (tujuh belas) sektor ekonomi, dan rata-rata pertumbuhan sektor ekonomi yang memberikan kontribusi paling besar pada tahun 2010 sampai dengan 2017 adalah pertanian, kehutanan, dan perikanan yaitu sebesar $17,05 \%$. Sementara total laju pertumbuhan ekonomi Karimun dari tahun 2010-2017 mengalami penurunan atau perlambatan sebesar $7,15 \%$ kemudian semakin menurun menjadi 5,42\% pada tahun 2017.

Penyebab terjadinya penurunan total laju pertumbuhan ekonomi di Kabupaten Karimun disebabkan adanya pelambatan laju pertumbuhan sektor pertanian, kehutanan, dan perikanan dari tahun 2010-2017 sebesar 2,67\%.

Berikut adalah data laju pertumbuhan ekonomi sektor pertanian, kehutanan, dan perikanan.

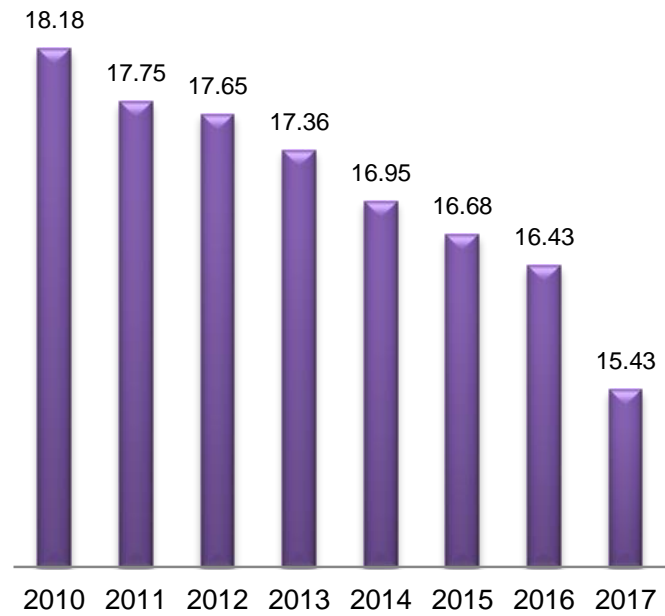

Gambar 1 Laju Pertumbuhan Sektor Pertanian, Kehutanan, dan Perikanan (dalam \%).

Penurunan laju pertumbuhan ekonomi sektor pertanian, kehutanan, dan perikanan disebabkan oleh subsesktor utama penyusun sektor ini yaitu sektor perikanan yang mengalami penurunan beberapa tahun terakhir. Subsektor perikanan memberikan kontribusi sebesar $71,61 \%$ pada tahun 2017 dan sedikit lebih rendah dari tahun 2016 yaitu sebesar $71,80 \%$ dan pada tahun 2015 sebesar 72,05\%.

Sektor pertanian, kehutanan, dan perikanan memliki potensi sumberdaya yang dapat dikembangkan. Salah satunya adalah sektor perikanan. Menurut data dari BPS Karimun penurunan PDRB untuk sektor pertanian, kehutanan, dan perikanan pada tahun 2017 cenderung disebabkan oleh penurunan peranan subsektor perikanan. Peranan subkategori perikanan turun dari $11,96 \%$ di tahun 2016 menjadi $11,27 \%$ di tahun 2017 dan pertumbuhan nilai tambah bruto subkategori perikanan mengalami kontarksi sebesar 1,09 persen (BPS Karimun, 2018).

Untuk mencapai pertumbuhan ekonomi daerah yang optimal maka kebijakan utama yang perlu dilakukan oleh pemerintah daerah adalah mengusahakan agar prioritas pembangunan dilaksanakan sesuai dengan potensi yang dimilliki oleh daerah yang bersangkutan. Dengan demikian, pengembangan potensi ekonomi sektor unggulan yang memberikan kontribusi terbesar terhadap kemajuan ekonomi daerah merupakan prioritas kebijakan yang harus dilaksanakan (Sumarsono, 2017).

Dengan melihat adanya potensi subsektor perikanan yang dapat dikembangkan di Kabupaten Karimun. Potensi lokal ini jika dimanfaatkan secara optimal dapat menjadi komoditas unggulan daerah yang kompetetif. 
Komoditas unggulan merupakan komoditas andalan yang memiliki posisi startegis berdasarkan pertimbangan tekbis maupun sosial ekonomi dan kelembagaan (pengusaan teknologi, kemampuan sumber daya manusia, infrastruktur dan kondisi budaya setempat) untuk dikembangkan di suatu wilayah..

\section{Perumusan Masalah}

Berdasarkan latar belakang yang telah diuraikan, rumusan masalah yang akan dibahas yaitu untuk menentukan sektor basis dan komoditas unggulan pada subsektor perikanan di Kabupaten Karimun untuk mengetahui prioritas pengembangan potenis daerah pada subsektor perikanan agar membantu meningkatkan laju pertumbuhan ekonomi di Kabupaten Karimun.

\section{Metode Penelitian}

Bagian ini akan dibahas metodemetode yang akan digunakan untuk menyelesaikan permasalahan dalam penelitian ini.

\section{Location Quotient (LQ)}

Dalam menganalisa keunggulan suatu komoditas, salah satunya adalah dengan pendekatan sektor basis. Sektor basis memiliki peranan penting sehingga dampak peningkatan besarannya akan membawa pengaruh terhadap peningkatan sektor lainnya. Analisis potensi wilayah pada penelitian ini yaitu penentuan sektor basis sektor perikanan di Kabupaten Karimun dengan pendekatan Location Quetient (LQ) (Sutejo, 2018).

Location Quetient (LQ) yang dihitung dalam penelitian ini adalah analisis yang berdasarkan Produk Domestik Regional Bruto (PDRB) khusunya pada subsektor perikanan. Subsektor perikanan di Kabupaten Karimun anatara lain budidaya perikanan, perikanan tangkap, dan pengolahan hasil perikanan.

Pada penelitian ini sektor yang dibandingkan adalah sektor perikanan di Kabupaten Karimun dan sektor perikanan di Kepulauan Riau dengan membandingkan PDRB dari subsektor perikanan di masing-masing wilayah dari tahun 2010 sampai dengan tahun 2017.

Perhitungan Location Quetient (LQ) digunakan untuk menentukan sektor basis pada sektor perikanan dari masing-masing subsektor industri perikanan yaitu budidaya, pengolahan, dan perikanan tangkap. Jika hasil perhitungan nilai $L Q>1$, maka dapat disimpulkan bahwa sektor tersebut merupakan sektor basis serta memiliki potensi untuk dikembangkan sebagai penggerak perekonomian sektor perikanan. Sebaliknya jika nilai $L Q<1$, maka sektor tersebut bukan merupakan sektor basis dan kurang potensial untuk dikembangkan sebagai penggerak perekonomian sektor perikanan di Kabupaten Karimun.

Adapun perhitungan LQ pada penelitian ini adalah sebagai berikut:

$\mathrm{LQ}=\frac{\mathrm{v} / 2 \mathrm{vt}}{\mathrm{V} / / \sum \mathrm{Vt}}$

Keterangan:

vi : PDRB sektor perikanan Kabupaten Karimun pada tahun 2010

$\sum \mathrm{vt}$ : PDRB total sektor perikanan tahun 20102017

Vi : PDRB sektor perikanan Provinsi Kepulauan Riau pada tahun 2010

$\sum \mathrm{Vt}$ : PDRB total sektor perikanan tahun 2010-2017

\section{Analytical Hierarchy Process (AHP)}

Analytical Hierarchy Process (AHP) merupakan suatu model pendukung keputusan. Model ini digunakan untuk menentukan komoditas unggulan pada subsektor industri perikanan yang merupakan sektor basis berdasarkan hasil perhitungan Location Quotient (LQ).

Langkah yang dilakukan adalah membuat penyusunan hirarki prioritas. Selanjutnya menentukan susunan prioritas elemen pada AHP dengan menyusun perbandingan berpasangan kemudian membandingkan dalam bentuk elemen matriks untuk setiap sub hirarki (Alfian, 2013) (Firmansyah,2013).

1. Uji Konsistensi Indeks dan Rasio

Analytical Hierarchy Process (AHP) mentoleransi tingkat konsistensi sebesar kurang dari $10 \%$, jika lebih dari $10 \%$ tingkat konsistensinya maka responden dianggap tidak konsisten dalam mengisi penilaian perbandingan berpasangan dan harus dilakukan perbaikan atas penilaian yang diberikan. Selanjutnya jika rasio konsistensi $<0,1$ maka penilaian yang diberikan oleh expert sudah mendekati sempurna atau mendekati valid dengan konsistensi $100 \%$. Adapun perhitungan uji konsistensi pada AHP adalah sebagai berikut:

$\mathrm{Cl}=\frac{\lambda_{\text {maks }}-\mathrm{n}}{\mathrm{n}-1}$

Keterangan:

$\mathrm{n}$ : banyaknya krteria

$\mathrm{Cl}$ : indeks konsistensi

$\mathrm{CR}=\frac{\mathrm{Cl}}{\mathrm{IR}}$

Keterangan:

$\mathrm{CR}$ : rasio konsistensi

IR : indeks Random 


\section{Hasil dan Pembahasan}

\section{Analisis Location Quotient (LQ)}

Analisis LQ digunakan untuk melihat apakah subsektor perikanan di Kabupaten Karimun, yaitu sektor perikanan tangkap, sektor budi daya, dan sektor pengolahan hasil perikanan memiliki peran yang besar serta prospektif untuk dikembangkan

Tabel 1 PDRB Sektor Perikanan di Kabupaten Karimun dan Provinsi Kepulauan Riau, 2010-2017

\begin{tabular}{|c|c|c|}
\hline Tahun & $\begin{array}{c}\text { Kabupaten } \\
\text { Karimun }\end{array}$ & $\begin{array}{c}\text { Prov. } \\
\text { Kepulauan } \\
\text { Riau }\end{array}$ \\
\hline 2010 & $707.678,05$ & $2.853 .800,93$ \\
\hline 2011 & $769.897,99$ & $3.057 .819,96$ \\
\hline Tahun & $\begin{array}{c}\text { Kabupaten } \\
\text { Karimun }\end{array}$ & $\begin{array}{c}\text { Prov. } \\
\text { Kepulauan } \\
\text { Riau }\end{array}$ \\
\hline 2012 & $874.074,15$ & $3.370 .338,86$ \\
\hline 2013 & $964.740,22$ & $3.797 .232,49$ \\
\hline 2014 & $1.077 .654,29$ & $4.219 .886,19$ \\
\hline 2015 & $1.157 .655,38$ & $4.614 .090,55$ \\
\hline 2016 & $1.251 .602,26$ & $5.108 .291,62$ \\
\hline 2017 & $1.283 .366,42$ & $5.201 .899,15$ \\
\hline
\end{tabular}

(Sumber: Badan Pusat Statistik, 2018).

Untuk mencari industri basis ekonomi sektor perikanan di Kabupaten Karimun di pasar daerah maupun di luar daerah yang bersangkutan, maka penjualan ke luar daerah tersebut akan menghasilkan pendapatan bagi daerah tersebut. Peningkatan pendapatan pada subsektor perikanan tangkap akan mendorong kenaikan investasi pada subsektor budi daya dan juga subsektor pengolahan serta sektor lainnya. Dengan demikian, keberadaan sektor basis tidak terlepas dari pengaruh sektor non basis dan sebaliknya, sektor basis dapat mempengaruhi sektor non basis. Berikut adalah hasil nilai LQ analisis sektor basis pada subsektor perikanan di Kabupaten Karimun:

1. Location Quotient tahun 2010

Berikut perhitungan Location Quotient dengan menggunakan persamaan (1) :

$$
\begin{aligned}
\text { PerikananTangkap } & =\frac{655805.25 / 707678.05}{1427185.84 / 2853800.93} \\
& =\frac{0.925}{0.500} \\
& =1,85
\end{aligned}
$$

$$
\begin{array}{ll}
\text { Budi Daya } & =\frac{29510.17 / 707678.05}{1168631.48 / 2853800.93} \\
& =\frac{0.042}{0.409} \\
& =0,102 \\
\text { Pengolahan } \quad & =\frac{22362.63 / 707678.05}{257983.61 / 2853800.93} \\
& =\frac{0.032}{0.090} \\
& =0,35
\end{array}
$$

Tabel 2 Nilai LQ Subsektor Perikanan Kabupaten Karimun, 2010-2017

\begin{tabular}{|c|c|c|c|}
\hline Tahun & $\begin{array}{c}\text { Perikanan } \\
\text { Tangkap }\end{array}$ & $\begin{array}{c}\text { Budi } \\
\text { Daya }\end{array}$ & Pengolahan \\
\hline 2010 & 1,85 & 0,10 & 0,35 \\
\hline 2011 & 1,12 & 0,38 & 0,38 \\
\hline 2012 & 1,19 & 0,20 & 0,66 \\
\hline 2013 & 1,34 & 0,35 & 0,03 \\
\hline 2014 & 1,28 & 0,23 & 0,22 \\
\hline 2015 & 1,25 & 0,26 & 1,00 \\
\hline 2016 & 1,28 & 0,003 & 0,13 \\
\hline 2017 & 1,23 & 0,22 & 0,175 \\
\hline $\boldsymbol{\Sigma}$ & $\mathbf{1 , 3 2}$ & $\mathbf{0 , 2 1}$ & $\mathbf{0 , 3 6}$ \\
\hline
\end{tabular}

Hasil dari nilai LQ pada tahun 2010 sampai dengan tahun 2017 di subsekor perikanan, maka secara rata-rata dapat didefinisikan sektor yang merupakan sektor basis (nilai LQ > 1) adalah sektor perikanan tangkap (dengan nilai rata-rata LQ tahun 2010-2017 adalah 1,32). Sektor perikanan tangkap memiliki keunggulan yang dapat dikembangkan sehingga mampu memenuhi kebutuhan di daerah Kabupaten Karimun dan memiliki potensi untuk diekspor ke daerah di luar Kabupaten Karimun. Sedangkan sektor budi daya $(0,21)$ dan pengolahan $(0,36)$ mempunyai nilai $L Q<1$ sehingga dimasukkan sebagai sektor non basis di Kabupaten Karimun sehingga kurang potensial untuk dikembangkan dan dijadikan sebagai penggerak perekonomian di Kabupaten Karimun. Kemudian selanjutnya untuk menentukan komoditas unggulan pada subsektor perikanan tangkap dilanjutkan dengan menggunakan metode Analytical Hierarchy Process.

\section{Analisis Analytical Hierarchy Process (AHP)}

Analisis AHP digunakan untuk menentukan jenis komoditas unggulan yang ada di Kabupaten Karimun. Metode ini merupakan lanjutan dari analisis $L Q$, setelah didapat sektor basis dari sektor perikanan yaitu subsektor perikanan tangkap maka dilanjutkan dengan 
pembobotan pada metode AHP untuk menentukan komoditas unggulan atau potensi unggulan daerah pada subsektor perikanan tangkap.

Sistem pengambilan keputusan dengan menggunakan metode AHP dianalisis oleh pakar (expert) melalui pengisian kuesioner. Berdasarkan hasil diskusi bersama pakar, kriteria dalam penentuan komoditas unggulan pada perikanan tangkap di Kabupaten Karimun ada 7 kriteria, yaitu sumber daya manusia (SDM), alat tangkap (armada), fasilitas (BBM, GPS, dan lainlain), cuaca (musim), kuantitas hasil tangkap, harga jual, dan permintaan pasar.

Hirarki dalam pemilihan komoditas unggulan terdiri dari level nol, level satu, dan level dua. Level nol adalah goal (tujuan) yang ingin dicapai yaitu penentuan komoditas unggulan sektor perikanan tangkap, kemudian level satu adalah kriteria dalam penentuan komoditas unggulan perikanan tangkap di Kabupaten Karimun, dan level dua adalah alternatif komoditas unggulan.

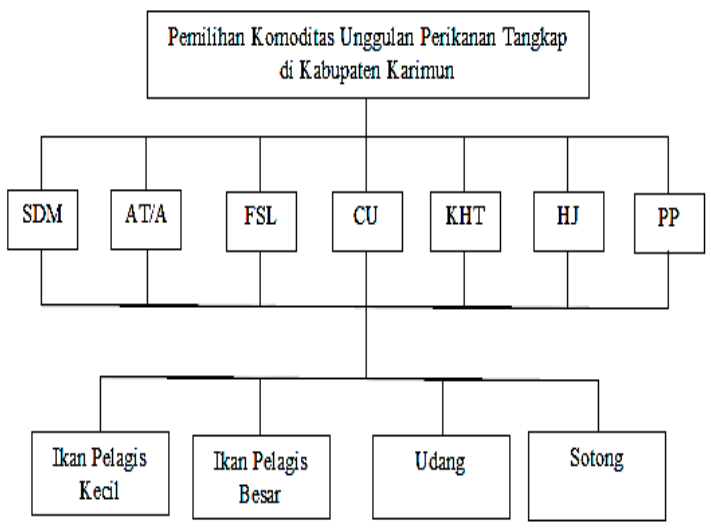

Gambar 2.Struktur Hirarki Perikanan Tangkap di Kabupaten Karimun

Hasil dari Pembobotan dapat dilihat pada gambar berikut:

$\square$ Kriteria

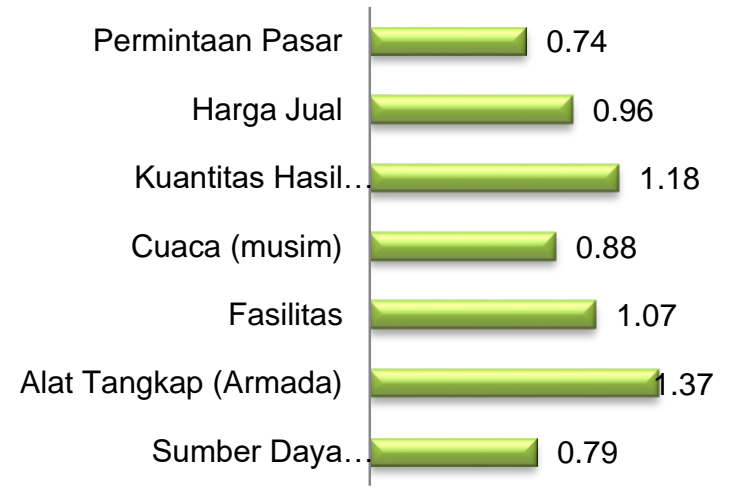

Gambar 3. Hasil Pembobotan Matriks Perbandingan Level-1

Berdasarkan (Gambar 2) dapat dilihat bobot nilai masing-masing kriteria subesektor perikanan tangkap, dimana kriteria yang berpengaruh terhadap penentuan komoditas unggulan pada sektor perikanan adalah alat tangkap (armada) dengan bobot yang paling tinggi yaitu 1,37 . kriteria ini merupakan hal utama dalam penentuan komoditas unggulan dikarenakan alat tangkap berperan penting dalam proses penangkapan ikan di Kabupaten Karimun. Alat tangkap yang digunakan berpengaruh terhadap hasil penangkapan ikan. Selain itu alokasi jumlah alat tangkap akan memudahkan dalam melakukan pengelolaan dan mencegah terjadinya fenomena overfishing. Kemudian disusul dengan kriteria kuantitas hasil tangkap $(1,18)$. Kriteria kuantitas hasil tangkap dalam penangkapan ikan yang meningkat memberikan nilai tambah yang lebih besar. Selanjutnya Kriteria fasilitas $(1,07)$ sebagai penunjang dalam proses penangkapan ikan, alokasi fasilitas yang tepat akan mengoptimalkan potensi sumberdaya ikan yang ada di Kabupaten Karimun.

Selanjutnya kriteria harga jual $(0,96)$. Harga jual dinilai penting dengan adanya peningkatan nilai tambah dan mendatangkan laba usaha pada subektor perikanan tangkap. Kemudian Kriteria cuaca atau musim $(0,88)$, yang juga berpengaruh terhadap kuantitas hasil tangkap, kriteria sumber daya manusia $(0,79)$ yang merupakan penggerak dalam proses penangkapan ikan dan terkahir adalah kriteria permintaan pasar $(0,74)$. Urutan tersebut berdasarkan bobot prioritas yang dihasilkan dari matriks perbandingan level-1 dimana kriteria yang mempunyai bobot tertinggi mendapatkan prioritas tertinggi dan seterusnya.

Setelah pembobotan prioritas kemudian dilanjutkan dengan uji konsistensi yang berfungsi untuk melihat apakah jawaban yang diberikan responden adalah konsistensi $100 \%$.

1. Menghitung Indeks Konsistensi

Hasil dari nilai $\mathrm{Cl}$ (Consistensi Index) dari penilaian para pakar dengan menggunakan persamaan (2):

$$
\begin{aligned}
\mathrm{Cl} & =\frac{7.71-7}{7-1} \\
& =\frac{0.71}{6} \\
& =0.12
\end{aligned}
$$

2. Rasio Konsistensi 
Setelah menghitung indeks konsistensi dilanjutkan dengan menghitung rasio konsistensi, yaitu untuk melihat apakah penilaian dari pakar konsistensi $100 \%$ atau mendekati valid. Nilai rasio konsistensi harus kurang dari 0,1. Perhitungan Rasio Konsistensi menggunakan persamaan (3):

$$
\begin{aligned}
\mathrm{CR} & =\frac{0.12}{1.32} \\
& =0.089
\end{aligned}
$$

Hasil uji konsistensi pada matriks perbandingan level-1 adalah 0,089 yang artinya perbandingan matriks kepentingan level kriteria ini konsistensi yang mendekati sempurna dan keputusan mendekati valid.

Kemudian dilanjutkan dengan matriks perbandingan level-2 atau level alternatif. Hasil diskusi bersama dengan pakar (expert) dalam bidang perikanan tangkap di Kabupaten Karimun yaitu alternatif yang digunakan untuk komoditas unggulan sektor perikanan tangkap adalah ikan pelagis kecil, ikan pelagis besar, udang dan sotong. Perbandingan tingkat kepentingan atau prioritas dihitung berdasarkan alternatif, Berikut adalah hasil grafik bobot prioritas pada level alternatif:

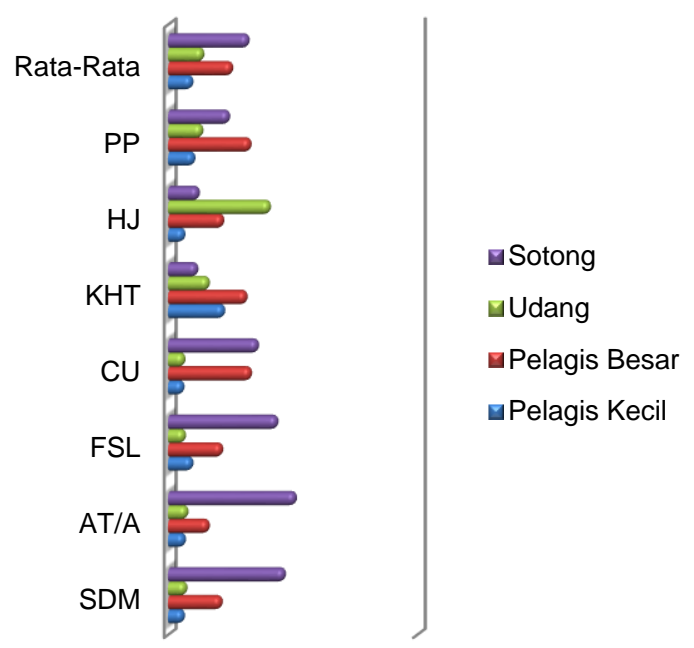

Gambar 3 Hasil Matriks Perbandingan Level-2

Tabel 3 Bobot Akhir Alternatif Komoditas Unggulan

\begin{tabular}{|c|c|c|}
\hline No & Komoditas & Bobot Akhir \\
\hline 1 & Sotong & 0.40489 \\
\hline 2 & Pelagis Besar & 0.30591 \\
\hline 3 & Udang & 0.16946 \\
\hline 4 & Pelagis Kecil & 0.11944 \\
\hline
\end{tabular}

Hasil matriks perbandingan untuk bobot akhir pada penentuan komoditas unggulan dapat dilihat pada (Tabel 3) yaitu sotong memiliki prioritas yang paling tinggi diantara komoditas lainnya. Bobot akhir komoditas sotong berdasarkan seluruh kriteria adalah $(0,40)$ kemudian disusul dengan komoditas ikan pelagis besar $(0,30)$, komoditas udang $(0,17)$ dan komoditas ikan pelagis kecil $(0,12)$. Kemudian hasil dari seluruh rasio konsistensi pada masingmasing kriteria kurang dari 0,1 maka perbandingan matriks kepentingan level alternatif ini konsistensi mendekati sempurna dan keputusan hasil expert mendekati valid.

\section{Simpulan}

Simpulan penelitian ini adalah:

1. Sektor yang merupakan sektor basis (potensial) pada subsektor perikanan adalah subsektor perikanan tangkap. berdasarkan perhitungan LQ dapat dilihat nilai LQ untuk perikanan tangkap dari tahun 2010-2017 adalah $L Q>1$ dengan rata-rata nilai $L Q$ adalah 1,32 yang artinya sektor ini merupakan sektor basis (potensial) untuk dikembangkan di Kabupaten Karimun.

2. Hasil dari pengambilan keputusan untuk menentukan komoditas unggulan pada sektor perikanan tangkap yang merupakan sektor basis adalah kriteria yang berpengaruh dalam pemilihan komoditas unggulan adalah alat tangkap (armada), kriteria ini merupakan aspek utama dalam penentuan komoditas unggulan dengan nilai bobot prioritas yaitu 0,40 . Kriteria dan merupakan prioritas pertama bagi pemerintah daerah untuk meningkatkan perekonomian pada sektor perikanan tangkap. Kemudian disusul dengan kuantitas hasil tangkap, fasilitas, harga jual, cuaca (musim), sumber daya manusia dan terakhir permintaan pasar. Untuk komoditas yang merupakan komoditas unggulan atau prioritas unggulan dan berpotensi untuk meningkatkan perekonomian pada sektor perikanan di Kabupaten Karimun adalah komoditas sotong, kemudian disusul dengan ikan pelagis besar, udang dan terakhir adalah ikan pelagis kecil.

3. Perkembangan dan laju pertumbuhan ekonomi dapat berpengaruh terhadap perubahan sektor basis dan komoditas unggulan, untuk itu perlu dilakukan penelitan lebih lanjut terkait informasi potensi yang 
dimiliki daerah Kabupaten Karimun demi analisis kebijakan pembangunan ekonomi daerah yang akan datang.

\section{Daftar Pustaka}

Alfian, Ignatius A. Sandy, Hanif Fathurahman (2013). Penggunaan Metode Analytic Network Process (ANP) dalam Pemilihan Supplier Bahan Baku Kertas pada PT Mangle Panglipur, Jurnal Rekayasa Sistem Industri Vol. 2, No.1.

Diana., Metode dan Aplikasi Sistem Pendikung Keputusan. Yogyakarta: Deepublish, 2018.

Firmansyah, Rizky., "Analisis Penentuan Sektor Unggulan Perekonomian Dengan Metode Analytical Hierarchy Process (AHP) dan Shift Share Terhadap Pertumbuhan Ekonomi (Studi di Kota Malang)". Jurnal IImiah, 2013.

Sapriadi dan Hasibullah., "Analisis Penentuan Sektor Unggulan Perekonomian Kabupaten Bulukumba". Iqtisaduna, Volume 1 Nomor 1. Hal 71-86, 2015.

Sutejo, B., Amin, M. K., dan Sari., "Perencanaan Pengembangan Industri di Propinsi Kalimantan Timur dengan Mengintegrasikan Metode Location Quotient dan Analisis Bertingkat". Jurnal Optimasi Sistem Industri, Vol 11 No.1, 2018.
Sumarsono, H., Nasikh., dan Muslikah, S., Indegenous Ekonomi Pembangunan Daerah. Malang: Gunung Samudera, 2017.

Tjandra, W. R., Hukum Keuangan Negara. Jakarta: Gramedia Widisarana Indonesia, 2009. 
Halaman ini sengaja dikosongkan This page is intentionally left blank 